\title{
Cheatgrass competition and establishment of desert needlegrass seedlings
}

\author{
DAWN L. RAFFERTY AND JAMES A. YOUNG
}

Authors are formerly research assistant and range scientist, USDA/ARS, Exotic and Invasive Weed Management Research Unit, 920 Valley Rd., Reno, Nev. 89512. Current address of first author, Nevada Department of Agriculture, 350 Capital Hill, Reno, Nev. 89502.

\begin{abstract}
Desert needlegrass (Achnatherum speciosum [Trin. \& Rupr.] Barkworth) is potentially a valuable native species for use in restoration seedings in the more arid portions of the Great Basin. Seedlings of desert needlegrass were grown in a greenhouse with 5 different densities of cheatgrass (Bromus tectorum L.). The densities of cheatgrass used in the greenhouse experiments were derived from sampling populations in the field where desert needlegrass is adapted and seedling recruitment is desired. Cheatgrass is known to close sites to the establishment of seedlings of perennial grasses through competition for moisture. The response variable was height of desert needlegrass shoots. Height measurements were taken weekly for 12 weeks following seedling emergence. During the first 5 weeks following emergence there were no significant $(P \leq 0.05)$ differences in the height of desert needlegrass seedlings among treatments. From week 5 through week 12 , there was a highly significant $(P \leq$ 0.001) difference in the height of desert needlegrass shoots between the control and all levels of cheatgrass density. Reducing the density of cheatgrass seedlings in the greenhouse to the equivalent of $25 \%$ of the density present in the field still did not allow the establishment of the perennial grass seedlings. Even though desert needlegrass is adapted for natural establishment in the drier portions of the central Great Basin, some form of cheatgrass control is required for the perennial grass seedling establishment if cheatgrass is present. Cheatgrass control has to be more than a reduction in density, it has to be near complete control of the annual grass.
\end{abstract}

Key Words: Achnatherum speciosum, Bromus tectorum, restoration, temperate deserts.

Revegetation attempts in semi-arid environments of the Great Basin often fail due to competition from the exotic annual cheatgrass (Bromus tectorum L.) (Robertson and Pearce 1945, Evans 1961, Harris 1967, Nelson et al. 1970, Aguirre and Johnson 1991, Monsen 1992, Nasri and Doescher 1995). The nature of this competition between cheatgrass and seedlings of perennial species has been investigated in numerous studies (Hull 1963, Melgoza et al. 1990, Francis and Pyke 1996).

In the drier portions of Great Basin rangeland, areas with 100 to $200 \mathrm{~mm}$ of annual precipitation, revegetation attempts have seldom been attempted because of the lack of suitable plant mate-

Research was funded in part by Tuscarora Gas Transmission Company Authors wish to thank D. E. Palmquist for assistance in the statistical analysis.

Manuscript accepted 17 April. 01.

\section{Resumen}

El "Desert needlegrass" (Achnatherum speciosum [Trin. \& Rupr.] Barkworth) es una especie nativa potencialmente valiosa para uso con fines de siembras para restaurar las porciones mas áridas de la Gran Cuenca. En un invernadero se cultivaron plántulas de "Desert needlegrass" con 5 diferentes densidades de "Cheatgrass" (Bromus tectorum L.). Las densidades de "Cheatgrass"utilizadas en los experimentos de invernadero se derivaron de muestreos de poblaciones en el campo donde el "Desert needlegrass" es adaptado y se desea el establecimiento de plántulas. El "Cheatgrass"es conocido por cerrar los sitios para el establecimiento de plántulas de zacates perennes mediante la competencia por humedad. La variable respuesta fue la altura de los tallos del "Desert needlegrass". La altura se midió semanalmente por 12 semanas después de la emergencia de las plántulas. Durante las primeras 5 semanas después de la emergencia la diferencia de altura de las plántulas de "Desert needlegrass" no fue significativa $(P \leq \mathbf{0 . 0 5})$ entre tratamientos. De la semana 5 a la 12 la diferencia de altura de los tallos de "Desert needlegrass" entre el tratamiento control y todos los niveles de densidad de "Cheatgrass" fue altamente significativa ( $P \leq 0.001)$. $\mathrm{Ni}$ aun reduciendo en el invernadero la densidad de plántulas de "Cheatgrass" a un equivalente del $25 \%$ de la densidad presente en el campo permitió el establecimiento de plántulas de zacates perennes. Aunque el "Desert needlegrass" esta adaptado para el establecimiento natural en la porciones más secas de la Gran Cuenca central, si el "Cheatgrass"esta presente se requiere algún grado de control de esta especie para que ocurra el establecimiento de plántulas de zacates perennes. El control del "Cheatgrass" tiene que ser mas que una reducción en la densidad. Tiene que ser casi un control completo del zacate anual.

rial. If the site is too dry for crested wheatgrass (Agropyron desertorum [Fischer] Schultes) revegetation has seldom been attempted except on sand where Indian ricegrass (Achnatherum hymenoides [Roemer \& Schultes] Barkworth) has been successfully established from seeding (Young et al. 1995). Disturbance does occur in these near arid environments in the form of utility and highway construction. The contractors for such projects are required to attempt to revegetate the disturbed areas. Obviously, an adapted source of a native plant material is required for these attempts.

Desert needlegrass (Achnatherum speciosum [Trin. \& Rupr.) Barkworth) is a perennial bunchgrass native to some of the driest portions of the temperate deserts of the Great Basin that have non-salt affected soils (Young and Evans 1980). Among the Achnatherum species, desert needlegrass is fairly unique in hav- 
ing seeds that readily germinate without the constraints of dormancy.

Field work associated with this study was conducted on the right-of-way of a large natural gas transmission line that crosses the base of the Dog Skin Mountains some $35 \mathrm{~km}$ north of Reno, Nev. (39 51' N, $119^{\circ} 48^{\prime} \mathrm{W}$ ).

Pipeline rights-of-way, like mining exploration roads, create a unique revegetation problem on semi-arid rangelands. They create linear disturbances that cross many plant communities and pastures. It is seldom feasible to fence these linearly disturbed areas to prevent grazing during the seedling establishment stage. Because of the relatively short distance across such linearly disturbed areas and the obvious large edge effect, it is often possible to encourage spontaneous seedling recruitment from the adjacent, undisturbed plant communities (Young et al. 1995). Unfortunately, if the adjacent vegetation happens to include a highly invasive species such as cheatgrass, succession on the disturbed right-of-way is going to be truncated by the exotic weed. In the construction of large diameter pipelines, the excavation and burial process creates a raw, undeveloped soil in at least the center of the right-of-way. Such levels of soil disturbance create ideal conditions for invasive weeds. If the right-of-way is not returned to dominance by desirable perennial species, it will serve as a corridor for the movement of new invasive species. The passage of construction equipment and mulching with straw almost insures inoculation of the sites with new weeds.

Our purpose in this portion of the study of pipeline revegetation was to determine the effect of varying densities of cheatgrass on the growth and establishment of seedlings of desert needlegrass.

\section{Materials}

The study was conducted in a greenhouse located at Reno, Nev. Plants were grown in cylinders $95 \mathrm{~cm}$ deep by $30 \mathrm{~cm}$ in diameter. They were filled with soil collected from the pipeline right-of-way. The soils adjacent to the collection site are a coarse-loamy, mixed, mesic Xerollic Haplargid (Melgozoa et al. 1990). Seed of both cheatgrass and desert needlegrass were collected at the Dog Skin Mountains, adjacent to the field study site.

The density of cheatgrass seeds used in the experiment was arrived at by randomly locating plots along the utility corridor and counting the number of cheatgrass plants per unit of area. From the average density the following seeding densities were established: 1) $100 \%$ of field conditions, 283 seeds per cylinder; 2) $75 \%$ of field density, 212 seeds per cylinder; 3 ) $25 \%$ of field density, 71 seeds per cylinder; and 4) the control with no cheatgrass. A preliminary germination trial indicated the cheatgrass seeds collected had about $90 \%$ germination. Each cylinder was over planted by $10 \%$ and thinned after 7 days to insure the final densities were as designed. Desert needlegrass seeds were planted at the rate of 3 per cylinder and thinned after 7 days to 1 per cylinder. Both species were planted on the same day. Cheatgrass seeds were distributed equally over the soil surface and the desert needlegrass seeds planted in the center of the cylinder.

The soil in each cylinder was saturated and allowed to drain to field capacity prior to seeding. The surface soil was kept moist until emergence occurred. No further water was added until the 7 th week when seedlings of both species exhibited signs of severe moisture stress. After the $7^{\text {th }}$ week, 2 liter of water were added to each cylinder weekly.

The experimental design was completely randomized with 4 replications (cylinder) per treatment. The treatment design was 5 densities $\mathrm{x} 12$ weeks in a factorial on the random factor of weeks. The cheatgrass density was treated as a fixed effect. The data was analyzed with a one way analysis of variance with cylinders nested within density by week.

\section{Results and Discussion}

During the first 4 weeks there were no significant differences $(\mathrm{P}<0.05)$ in the shoot height of desert needlegrass seedlings among treatments. Beginning

Table 2. Mean desert needlegrass shoot height in $\mathrm{cm}$ in relation to cheatgrass density by week. Percentage density was calculated based on 3,875 cheatgrass plants per $\mathrm{m}^{2}$ as $100 \%$. Weeks 1 through 4 showed no significant differences and were not included in table . ${ }^{1}$

\begin{tabular}{|c|c|c|c|c|c|}
\hline \multirow{2}{*}{$\begin{array}{l}\text { Weeks } \\
\text { after } \\
\text { planting }\end{array}$} & \multicolumn{5}{|c|}{ Cheatgrass density } \\
\hline & 0 & 25 & 50 & 75 & 100 \\
\hline & & & $-(\mathrm{cm})$ & - & ----- \\
\hline 5 & $9.9 \mathrm{a}$ & $7.5 \mathrm{ab}$ & $6.9 \mathrm{ab}$ & $6.4 \mathrm{ab}$ & $5.9 b$ \\
\hline 6 & $12.4 \mathrm{a}$ & $7.5 b$ & $6.9 \mathrm{~b}$ & $6.6 \mathrm{~b}$ & $5.9 b$ \\
\hline 7 & $13.1 \mathrm{a}$ & $7.5 b$ & $6.8 \mathrm{~b}$ & $5.6 b$ & $5.0 \mathrm{~b}$ \\
\hline 8 & $13.2 \mathrm{a}$ & $6.3 b$ & $6.0 \mathrm{~b}$ & $4.4 b$ & $3.9 b$ \\
\hline 9 & $13.2 \mathrm{a}$ & $5.5 b$ & $4.6 \mathrm{~b}$ & $4.4 b$ & $4.0 \mathrm{~b}$ \\
\hline 10 & $13.3 \mathrm{a}$ & $5.9 \mathrm{~b}$ & $4.3 b$ & $3.8 \mathrm{~b}$ & $3.6 b$ \\
\hline 11 & $13.5 \mathrm{a}$ & $6.0 \mathrm{~b}$ & $4.8 \mathrm{~b}$ & $3.0 \mathrm{~b}$ & $3.0 \mathrm{~b}$ \\
\hline 12 & $13.9 \mathrm{a}$ & $6.3 b$ & $4.8 \mathrm{~b}$ & $3.3 b$ & $3.1 \mathrm{~b}$ \\
\hline
\end{tabular}

Means within rows followed by the same letter are not significantly different at the 0.055 level of probability as determined by Duncan's Multiple Range Test.
Table 1. Significant differences among densities as measured by desert needlegrass shoot height beginning in the $5^{\text {th }}$ week. Weeks on differences at the 0.05 level of probability.

\begin{tabular}{llll}
\hline \hline $\begin{array}{l}\text { Weeks from } \\
\text { planting }\end{array}$ & df & f-value & p-value \\
\hline 5 & 4 & 3.82 & 0.025 \\
6 & 4 & 7.00 & 0.002 \\
7 & 4 & 5.76 & 0.005 \\
8 & 4 & 6.36 & 0.003 \\
9 & 4 & 5.85 & 0.005 \\
10 & 4 & 7.33 & 0.002 \\
11 & 4 & 7.30 & 0.001 \\
12 & 4 & 7.73 & 0.001 \\
\hline
\end{tabular}

with the $5^{\text {th }}$ week of growth, there was a significant $(\mathrm{P}<0.001)$ main effect of cheatgrass density (Table 1). Both the control with no cheatgrass and the $100 \%$ of the field density of cheatgrass were significantly $(\mathrm{P}<0.05)$ different from the other 3 densities at week 5. From week 6 through week 12 , the control was significantly different from all other densities (Table 2).

Starting with the soil in the cylinders at field capacity and keeping the surface soil damp until emergence occurred allowed desert needlegrass to compete with cheatgrass for the first 4 weeks after planting. Apparently, as the root systems of cheatgrass plants occupied sufficient area of the soil within the cylinders, the competition for moisture became severe. Not even the addition of supplemental moisture would prolong the life of the desert needlegrass seedlings.

Research by Evans (1961) with a similar greenhouse experiments with cheatgrass and crested wheatgrass that was followed by extensive monitoring of micro-environmental conditions in the field (Evans et al. 1970), clearly determined that virtually total control of cheatgrass was necessary through 4 (data not shown) had no significant 
to insure the establishment of crested wheatgrass. Despite the natural adaptation of desert needlegrass to extremely arid conditions, cheatgrass can still out compete seedlings of the perennial for moisture. Cheatgrass only became abundant in the most arid portions of the Great Basin during the last 2 decades of the $20^{\text {th }}$ century (Young and Tipton 1990).

The need for weed control before seeding perennial grasses in right-of-way revegetation projects such as the one along the Dog Skin Mountains is obvious. However, in such industrial revegetation projects on rangelands the contracts for revegetation often ignore biological reality. The pipeline contractor often has to post a bond to insure restoration of the disturbed site. In such arid situations, fall seeding of perennial grasses gives the best results, but weed control has to wait until after cheatgrass germinates in the spring. In such arid situations cheatgrass rarely germinates in the fall. This requires a year delay in the revegetation process and prolongs the bonding period. Contractors for large transmission pipelines in non-petroleum producing areas are not always aware of local concerns and are not interested in prolonging the revegetation process once the construction is completed. Their request is for research agencies to provide them with an adapted perennial grass that will fit the environmental requirements of the site. The results of this study clearly illustrate this is impossible with out an adequate weed control program for cheatgrass. Industrial weed control and revegetation on utility rights-ofway on rangelands should be coordinated with grazing management systems for the pastures through which the construction passes. If the grazing management system accommodates a year of rest, make it the seedling year for the revegetation. This will create a patch work of weed control and revegetation activities instead of a continuous flow of revegetation along the rights-of-way, but it has a chance for successful revegetation of the disturbed sites.

Yes, such an approach would be more expensive, but if you can not afford to restore the rangeland environment, do not destroy the vegetation fabric in linear disturbance.

\section{Literature Cited}

Aguirre, L. and D. A. Johnson. 1991. Influence of temperature and cheatgrass competition on seedling development of two bunchgrasses. J. Range Manage. 44:347-354

Evans, R. 1961. Effects of different densities of downy brome (Bromus tectorum) on growth and survival of crested wheatgrass (Agropyron desertorum) in the greenhouse. Weeds 9:216-223.

Evans, R. A., H. R. Holbo, R. E. Eckert, Jr., and J. A. Young. 1970. Functional environment of downy brome communities in relation to weed control and revegetation. Weed Sci. 18:216-223.

Francis, M. G. and D. A. Pyke. 1996. Crested wheatgrass-cheatgrass seedling competition in a mixed-density design. J. Range Manage. 49:432-438.

Harris, G. A. 1967. Some competitive relationships between Agropyron spicatum and Bromus tectorum. Ecol. Monographs 37:89111.
Hull, A. C., Jr.. 1963. Competition and water requirements of cheatgrass and wheatgrass in the greenhouse. J. Range Manage. 16:199-203.

Melgoza, G., R. S. Nowak, and R. J. Tausch. 1990. Soil water exploitation after fire: competition between Bromus tectorum and 2 native species. Oecologia 83:7-13.

Monsen, S. 1992. The competitive influences of cheatgrass (Bromus tectorum) on site restoration. pp. 43-50, In S. B. Monsen and S. O. Kitchen (eds.) Proc. Sym. Ecology and Management of Annual Rangelands. Gen. Tech. Report, USDA, Forest Service, Odgen, Ut.

Nasri, M. and P. S. Doescher. 1995. Effect of competition by cheatgrass on shoot growth of Idaho fescue. J. Range Manage. 48:402-405..

Nelson, J. R., A. M. Wilson, and C. J. Goebel. 1970. Factors influencing broadcast seeding in bunchgrass ranges. J. Range Manage. 23:163-170.

Robertson, J. H. and C. K. Pearce. 1945. Artificial reseeding and the closed community. Northwest Sci. 19:58-68.

Young, J. A. and R. A. Evans. 1980. Germination of desert needlegrass. J. Seed Tech. 5:40-46.

Young, J. A. and F. Tipton. 1990. Invasion of cheatgrass into arid environments of the Lahontan basin. pp. 23-30 In: E. D. McArthur, E. M. Rommey, S. S. Smith, and P. T. Tueller (compilers) Proc. Sym. Cheatgrass Invasion, Shrub-die Off, and Other Aspects of Shrub Biology and Management. Gen, Tech Report 278, USDA, Forest service, Odgen, Ut.

Young, J. A., R. R. Blank, and W. S. Longland. 1995. Reclamation of open pit mining spoils in temperate desert environments. J. Arid Land Studies 4:161-167. 